Article

\title{
Food Consumption and COVID-19 Risk Perception of University Students
}

\author{
Stephanie Rodriguez-Besteiro ${ }^{1}$ (D) , Gabriel Valencia-Zapata ${ }^{2}$, Elisama Beltrán de la Rosa ${ }^{2}$ \\ and Vicente Javier Clemente-Suárez $1,3, *$ (i)
}

Citation: Rodriguez-Besteiro, S.; Valencia-Zapata, G.; Beltrán de la Rosa, E.; Clemente-Suárez, V.J. Food Consumption and COVID-19 Risk Perception of University Students. Sustainability 2022, 14, 1625

https://doi.org/10.3390/su14031625

Academic Editor: Ricardo

García Mira

Received: 10 January 2022

Accepted: 28 January 2022

Published: 30 January 2022

Publisher's Note: MDPI stays neutral with regard to jurisdictional claims in published maps and institutional affiliations.

Copyright: (C) 2022 by the authors. Licensee MDPI, Basel, Switzerland. This article is an open access article distributed under the terms and conditions of the Creative Commons Attribution (CC BY) license (https:// creativecommons.org/licenses/by/ $4.0 /)$.
1 Faculty of Sports Sciences, Universidad Europea de Madrid, Tajo Street, s/n, 28670 Madrid, Spain; stephanie.rodriguez@universidadeuropea.es

2 Programa de Psicologia, Universidad Metropolitana, Barranquilla 080002, Colombia; gvalenciaz@unimetro.edu.co (G.V.-Z.); elisama.beltran@unimetro.edu.co (E.B.d.1.R.)

3 Grupo de Investigación en Cultura, Educación y Sociedad, Universidad de la Costa, Barranquilla 080002, Colombia

* Correspondence: vctxente@yahoo.es; Fax: +34-911-413-585

\begin{abstract}
The aim of this study is to examine the differences in COVID-19 risk perception of university students, depending on their food consumption (proinflammatory diet and non-proinflammatory diet). A total of 513 university students aged between 16 and 42 years (PDG: mean 20.26, standard deviation 3.07; NPDG: mean 21.78, standard deviation 4.12) were interviewed via an online questionnaire. The study subjects were divided into two groups: a proinflammatory diet group (PDG) who obtained higher values on pasta, rice, bread, pastries, juices, and fruit consumption; and nonproinflammatory diet group (NPGD) who presented low consumption on these products. Significant results were obtained $(p<0.05)$ on how a proinflammatory diet presented a higher COVID-19 risk perception in university students (PDG 7.92 \pm 2.46 ; NPGD $7.12 \pm 2.28$ ). In addition, students with a proinflammatory diet presented lower values in depression (PDG $48.32 \pm 5.33$; NPGD $49.83 \pm 5.23$ ) and loneliness (PDG $4.91 \pm 1.67$; NPGD $5.14 \pm 1.68$ ) and higher values in openness to experience (PDG $7.5 \pm 1.53$; NPGD $7.20 \pm 1.54$ ) than students with a non-proinflammatory diet. Furthermore, students with a proinflammatory diet were most affected in work (loss of work, reduced work, or unaffected work) due to the COVID-19 crisis (PDG $2.54 \pm 0.65$; NPGD $3.99 \pm 0.26$ ). The proinflammatory diet group presented higher values in complying with the confinement rules than students with a non-proinflammatory diet (PDG $8.26 \pm 1.83$; NPGD $7.74 \pm 2.10$ ). The results of this study may be a useful tool to explain and prevent both the psychological and general health consequences of the COVID-19 pandemic in students.
\end{abstract}

Keywords: COVID-19; proinflammatory diet; students; risk perception; anxiety; personality

\section{Introduction}

The SARS-CoV-2 outbreak spread worldwide during the first months of 2020 and was classified as a pandemic by the World Health Organization in March 2020. [1]. Pandemics leave a significant imprint on the memory of society with effects that in many cases can become permanent. The COVID-19 pandemic has caused social disruption with effects on the economy, individual freedoms, and physical and mental health [2]. In this case, prolonged fear of contagion has created a great sense of uncertainty in the population. Isolation causes anxiety, sadness, anger, and loneliness. Social distancing and quarantines (total or perimeter), which have been established on numerous occasions, go against human nature [3]. Society has increased alcohol consumption while anxiety and insomnia problems are increasing [4]. In fact, people with a high anxiety trait, i.e., those who tend to suffer from anxiety in situations that generate a lot of uncertainty, could be one of the most affected groups during this last year [5]. 
As mentioned, COVID-19 has changed the way of life of several people, producing modifications in the food trends and habits of the general population [2]. The copious purchase of certain products for an unpredictable period, the stressful and uncertain situation during periods of confinement, or the implementation of remote work, are just some of the causes that have influenced differences in people's diets in the last year, resulting in diets rich in sugars and carbohydrates as well as saturated fats, which can have a negative impact on health [6].

In addition, it has been reported that Western countries tend to consume diets that do not include large amounts of fresh fruits or vegetables, thereby reducing the daily number of necessary antioxidants and vitamins, which have been identified as a good way to target COVID-19 [7]. Some studies point out that people who follow a healthy diet to a greater extent, protect themselves and their immune system, which is why there is an increased demand for functional foods containing bioactive ingredients [8]. Other research indicates that, for example, it was observed in Spain that diets throughout the confinement were much higher energetically but also had a lower nutritional quality than pre-COVID-19 dietary values $[8,9]$. This study indicated that people could consume in confinement up to $539 \mathrm{kcal}$ more than what was recommended, just because the foods consumed were of lower nutritional quality. Moreover, compared to the same period in 2019, a $6 \%$ increase in daily food intake was found, with a total average consumption of $2509 \mathrm{kcal}$ during confinement $[9,10]$. One of the factors that could influence this energy increase could be related to having to stay at home for such a long period of time, as well as telecommuting, leading people to eat larger amounts of food due to cravings produced by boredom and stress $[9,11]$.

COVID-19 has modified the frequency and intake amounts of some products [9,12]. One study showed that during confinement, Spaniards ingested lower amounts of beverages, slightly increased their intake of eggs and red meat, and showed a substantial increase in plant-based foods, such as nuts, pasta, rice, or processed vegetables, compared to the same period in 2019 [9,10]. Although these changes were found, red meat consumption remained above the recommended dietary guidelines, while plant-based food products remained below the recommended range [10].

On the other hand, it is curious that other research, which studied the effect of COVID-19 confinement on adolescents in Brazil, Chile, Colombia, Spain, and Italy showed results which indicated healthy dietary changes, increasing the consumption of vegetables, legumes, and fruits during confinement. They pointed out that adolescents consumed between $7.7 \%$ and $8 \%$ more of these products than before confinement. This was observed in an increase in the sale of legumes and fruits since the beginning of confinement and may also have been influenced by people having more time to cook at home [13]. A healthy and balanced diet could have been one of the personal strategies people adapted to avoid risks throughout the COVID-19 pandemic [14], due to the immunomodulatory effects that some macro-, microand phytonutrients have $[15,16]$. Similarly, nutritional deficiencies have been shown to be associated with increased susceptibility to viral infection and a worse clinical course of the disease $[15,16]$. Therefore, although a healthy diet does not prevent infection, it may play an important role in the response of individuals to the infectious agent [17].

In this line, researchers have established an association between diet and people's mood [18]; some have found that the consumption of sweets and pastries was more common in women than in men and, on the contrary, the consumption of fast food was more common in men. As well, consumption of fresh fruits, cooked salads and vegetables, dairy products, and cereals was only slightly more common in women, while consumption of soft drinks/lemonade, meat, and fish was more common in men. Therefore, women showed higher scores for depressive symptoms and perceived stress than men [18]. Previous research showed how the introduction of anti-inflammatory nutrition habits improved the symptomatology of psychopathologies, such as anxiety and depression [19]. In the same way, some research has studied those modifications in nutritional habits and physical activity could be closely related to mental health, since both have a strong anti-inflammatory effect on the body and can prevent the symptoms of some pathologies, such as depres- 
sion [19]. Contextual situations, including a lack of physical exercise or poor diet, can lead to hyperactivation of the sympathetic autonomic nervous system. The inclusion of training sessions together with nutritional recommendations induces a modification of the subject's previous habits for healthier ones and could lead to physiological modifications that reduce the incidence of psychological pathologies [20].

Thus, we conducted the present research with the aim of studying the differences in the COVID-19 risk perception of university students at the Metropolitan University of Barranquilla (Colombia) according to their food consumption (proinflammatory diet: a kind of diet that can predispose the body to diseases, as well as anxiety, ultra-processed foods, high in calories and very low in vegetables and fruits, are related to higher levels of inflammation; and non-proinflammatory diet: those rich in fruits, legumes, olive oil, oily fish, vegetables, and whole grains have been associated with lower inflammatory markers) [21]. Analysis was also carried out on the differences in other variables, such as academic and work environment, psychological profile, and physical activity.

\section{Materials and Methods}

In the current study, 513 university students from Universidad Metropolitana of Barranquilla (Colombia) aged between 16 and 42 years were interviewed via an online questionnaire. To prevent double responses from the same person, students were required to include their Student ID, which must match with the university database. Furthermore, data were considered strictly confidential. The inclusion criteria were that they were students matriculated since the beginning of the academic year. An e-mail was sent to the students to ask for their voluntary participation, so they could refuse to complete the questionnaire. Finally, 513 from 5500 students completed the questionnaire. This research complied with the Helsinki declarations (revised in Brazil, 2013) on human research and was approved by the University Ethics Committee (CIPI/18/074). All participants digitally signed a consent to participate where the aims and procedure of the study was explained.

In line with previous research [22], an adapted previously used food consumption frequency questionnaire was conducted to identify proinflammatory or non-proinflammatory diets. The first two questions were related to eating habits. The rest of the 16 questions were on the consumption frequency of different food groups, including fish, pasta, rice, bread, pastries, juices, fruit, vegetables, legumes, meat, fast food, and soft drinks, in which answers ranged from "less than two per week" to "seven or more per week". The study subjects were divided into two groups: the first being the proinflammatory diet group (PDG), those who obtained higher values (with consumption of 3 to 7 times or more per week) on the consumption of pasta, rice, bread, pastries, juices, and fruit [7]; the second group being the non-proinflammatory diet group (NPGD) included those participants who did not obtain these values (with consumption 2 times or less per week). In total, 212 students belonged to the PDG and 298 belonged to the NPDG.

The following parameters were analyzed.

Age and anthropometric variables: Gender, age (years), height $(\mathrm{cm})$, weight $(\mathrm{kg})$, and body mass index (BMI, $\mathrm{kg} / \mathrm{m}^{2}$ ) were obtained

Employment variables: Analysis was carried out as to whether the student performed some type of paid work and if so, whether this has been affected by the COVID-19 crisis (the response options were "not affected" "the number of working hours and income have been reduced" or "has lost his or her job").

Descriptive variables related to the COVID-19 crisis: Questions covered included: perception of the risk of the COVID-19 virus assessed with a Likert scale from 0 to 10; how the COVID-19 crisis will affect academic performance, with five response options ranging from very negative to very positive; how the COVID-19 crisis has affected respondents on a personal level, on a Likert scale from 0 to 10; the degree of compliance with the confinement due to the COVID-19 crisis, as in the previous item, a Likert scale was used where 0 means the least and 10 means the most; how many people have lived with the individual during the confinement, this was measured on a self-perception scale, indicating the number of 
people with whom the student lived. Two questions were included in the questionnaire: the first was about how many hours on average the person slept per day (with a scale from $5 \mathrm{~h}$ or less to more than $9 \mathrm{~h}$ ), and the second question asked about the quality of sleep the person had the previous day, on a Likert scale from 1 (very poor sleep quality) to 10 (very good sleep quality). Average number of steps per day in the last week was also measured through a self-perception scale, in which the number of steps the student took in the last week was indicated.

Food consumption variable: A food consumption frequency questionnaire was analyzed, in which the frequency of consumption and quantities of each food were asked (juices $250 \mathrm{~mL}$, alcoholic beverage $250 \mathrm{~mL}$, fermented beverage $250 \mathrm{~mL}$, soft drinks $250 \mathrm{~mL}$, energy drink $250 \mathrm{~mL}$, fruit $90 \mathrm{~g}$, bakery/sweets $90 \mathrm{~g}$, meat $150 \mathrm{~g}$, fish $150 \mathrm{~g}$, legume $200 \mathrm{~g}$, pasta or rice $150 \mathrm{~g}$, vegetables $200 \mathrm{~g}$, bread $50 \mathrm{~g}$, and fast food $180 \mathrm{~g}$ ).

Psychological profile: Based on the Spanish version of the Big Five Inventory (alpha coefficient 0.73) [23], the reduced version of the Big Five personality traits of 44 items was used, consisting of: openness to experience, conscientiousness, extraversion, agreeableness, and neuroticism. It is composed of 10 items that are answered using a 5-point Likert scale, where 1 means completely disagree and 5 means completely agree. Based on the Spanish version of the Spielberger State-Trait Anxiety Inventory (alpha coefficient 0.93) [24], the reduced version was used, and composed of 6 items assessing anxiety with answers on a 4-point Likert scale where 1 means not at all and 4 means very much. The Spanish version of the Acceptance and Action Questionnaire II (alpha coefficient.84 (0.78-0.88)) [25] was used; this test analyzes experiential avoidance or psychological inflexibility through 7 items that are answered using a 7-point Likert scale, where 0 means never and 7 means always. The Spanish version of the UCLA Loneliness Scale (alpha coefficient 0.94) [26], which measures loneliness, was used. A condensed version consisting of 3 items answered by a 3-point Likert scale, where 1 means never and 3 means frequently, was used in this research. The Spanish version of the Zung Depression Scale (alpha coefficient 0.09) $[27,28]$ in relation to the COVID-19 crisis was used. The self-applied scale for depression has a sensitivity and specificity of over $80 \%$ and consists of 20 items formulated in positive and negative terms. Somatic and cognitive symptoms are highly relevant, with eight items for each group, and the scale is completed with two items referring to mood and two to psychomotor symptoms.

Physical Activity Habits: This variable was analyzed by means of a questionnaire used in line with previous research, which evaluated the psychophysiological stress response in a context of high psychological demand that included these questions: "Did you do any physical activity in the last 7 days?", "If so, time in minutes of cyclic and/or aerobic activity (cycling, treadmill, Zumba) adding up all the sessions of the 7 days", "If so, time in minutes of activity with self-loads (sit-ups, push-ups, squats ... ) or weights (gym machines, weights...) adding up all the sessions of the 7 days".

\section{Statistical Analysis}

Statistical analyses were performed with the Statistical Package for the Social Sciences (SPSS) version 24.0 (SPSS Inc., Chicago, IL, USA). Descriptive statistics (mean and standard deviation) were calculated for each of the variables. Kolmogorov-Smirnov tests were performed to analyze the normality and homogeneity of each variable. An independent t-test was performed to analyze the differences in nutrition in the sociodemographic, academic, and psychological variables. The significance level was set at $p<0.05$, according to conventions.

\section{Results}

Data are presented as mean \pm standard deviation. Age differences were found between groups. (Table 1). No differences were found in the anthropometric variables. 
Table 1. Differences in anthropometric variables between groups.

\begin{tabular}{ccccccc} 
& & & & & \multicolumn{2}{c}{$\begin{array}{c}\text { C5\% Confidence Interval of } \\
\text { the Difference }\end{array}$} \\
\hline Variable & PDG & NPGD & t & $p$ & Lower & Upper \\
\hline Age (years) & $20.26 \pm 3.07$ & $21.78 \pm 4.12$ & -4.536 & $>0.001$ & -2.180 & -0.862 \\
Height $(\mathrm{cm})$ & $164.56 \pm 9.19$ & $165.36 \pm 9.19$ & -0.983 & 0.326 & -2.402 & 0.800 \\
Weight $(\mathrm{kg})$ & $62.63 \pm 13.72$ & $61.83 \pm 11.52$ & 0.711 & 0.478 & -1.406 & 3.001 \\
Body Mass Index $\left(\mathrm{kg} / \mathrm{m}^{2}\right)$ & $23.01 \pm 3.90$ & $22.57 \pm 3.58$ & 1.302 & 0.194 & -0.221 & 1.091 \\
\hline
\end{tabular}

PGD (proinflammatory diet group), NPDG (non-proinflammatory diet group).

Regarding academic and COVID-19 perception variables, group differences were found in the semester in which the students were. The PDG was more affected by work due to the COVID-19 crisis. Regarding the PDG, 41 students were employed part-time, 6 students were employed full-time, and 163 students were unemployed. For the NPDG group, 62 students were employed part-time, 11 students were employed full-time, and 223 students were unemployed. Likewise, the PDG had a higher level of risk perception in the COVID-19 virus, which is reflected in higher compliance with confinement due to the COVID-19 crisis given that the results indicate that they lived with a greater number of people (Table 2).

Table 2. Differences in academic and COVID-19 perception variables between groups.

\begin{tabular}{|c|c|c|c|c|c|c|}
\hline \multirow[b]{2}{*}{ Variable } & \multirow[b]{2}{*}{ PDG } & \multirow[b]{2}{*}{ NPDG } & \multirow[b]{2}{*}{$\mathbf{t}$} & \multirow[b]{2}{*}{$p$} & \multicolumn{2}{|c|}{$\begin{array}{l}\text { 95\% Confidence Interval } \\
\text { of the Difference }\end{array}$} \\
\hline & & & & & Lower & Upper \\
\hline Average mark & $3.98 \pm 0.26$ & $3.99 \pm 0.26$ & -0.383 & 0.702 & -0.056 & 0.037 \\
\hline $\begin{array}{c}\text { Regarding your work. have you } \\
\text { been affected by the COVID-19 } \\
\text { crisis? }\end{array}$ & $2.54 \pm 0.65$ & $2.38 \pm 0.76$ & 2.161 & 0.031 & 0.014 & 0.309 \\
\hline $\begin{array}{l}\text { Level of perceived risk in the } \\
\text { COVID-19 virus }\end{array}$ & $7.92 \pm 2.46$ & $7.12 \pm 2.28$ & 3.796 & $>0.001$ & 0.388 & 1.221 \\
\hline $\begin{array}{c}\text { How do you think the COVID-19 } \\
\text { crisis will affect your academic } \\
\text { performance? }\end{array}$ & $3.30 \pm 1.24$ & $3.53 \pm 1.33$ & -1.933 & 0.054 & -0.454 & 0.003 \\
\hline $\begin{array}{l}\text { How has the COVID-19 crisis } \\
\text { affected you personally? }\end{array}$ & $6.83 \pm 2.10$ & $6.64 \pm 2.34$ & 0.973 & 0.331 & -0.200 & 0.595 \\
\hline $\begin{array}{l}\text { Degree of confinement compliance } \\
\text { due to the COVID-19 crisis }\end{array}$ & $8.26 \pm 1.83$ & $7.74 \pm 2.10$ & 2.879 & 0.004 & 0.164 & 0.869 \\
\hline $\begin{array}{l}\text { How many people have you lived } \\
\text { with in confinement? }\end{array}$ & $4.22 \pm 1.35$ & $3.77 \pm 1.40$ & 3.592 & $>0.001$ & 0.202 & 0.690 \\
\hline $\begin{array}{c}\text { How many hours do you sleep on } \\
\text { average per day? }\end{array}$ & $4.13 \pm 1.73$ & $4.08 \pm 1.84$ & 0.317 & 0.752 & -0.266 & 0.369 \\
\hline Quality of your sleep & $6.87 \pm 2.26$ & $6.71 \pm 2.15$ & 0.839 & 0.402 & -0.222 & 0.554 \\
\hline
\end{tabular}

PGD (proinflammatory diet group), NPDG (non-proinflammatory diet group).

Regarding the differences in food consumption between groups, significant differences were found in the consumption of juices, sugary drinks, fruit, bakery/sweets, meat, fish, legume, pasta or rice, vegetables, bread, and fast food, where in all of them, the PDG obtained higher consumption than the NPDG (Table 3). 
Table 3. Differences in food consumption variables between groups.

\begin{tabular}{ccccc}
\hline Variable & PDG & NPDG & t & p \\
\hline How many meals did you take on average & $4.49 \pm 1.45$ & $4.49 \pm 1.26$ & 0.002 & 0.998 \\
during your confinement? & & & & \\
How many glasses of water do you drink & $4.16 \pm 1.59$ & $4.19 \pm 1.56$ & -0.189 & 0.850 \\
per day? & $735 \pm 250$ & $452.5 \pm 232.5$ & 12.907 & $>0.001$ \\
Juices (mL) & $265 \pm 60$ & $272.5 \pm 90$ & -1.221 & 0.223 \\
Alcoholic Beverage (mL) & $275 \pm 90$ & $267.5 \pm 72.5$ & 0.738 & 0.461 \\
Fermented beverage (mL) & $507.5 \pm 0.232 .5$ & $382.5 \pm 182.5$ & 6.626 & $>0.001$ \\
Soft drinks (mL) & $262.5 \pm 65$ & $257.5 \pm 52.5$ & 0.546 & 0.585 \\
Energy Drink (mL) & $242.1 \pm 81.9$ & $173.7 \pm 72.9$ & 9.622 & $>0.001$ \\
Fruit (g) & $200.7 \pm 76.5$ & $138.6 \pm 59.4$ & 9.745 & $>0.001$ \\
Bakery/Sweets (g) & $463.5 \pm 117$ & $340 \pm 0.142 .5$ & 10.111 & $>0.001$ \\
Meat (g) & $357 \pm 148.5$ & $265.5 \pm 120$ & 7.399 & $>0.001$ \\
Fish (g) & $488 \pm 198$ & $384 \pm 168$ & 6.115 & $>0.001$ \\
Legume (g) & $517.5 \pm 91.5$ & $357 \pm 148.5$ & 13.743 & $>0.001$ \\
Pasta or rice (g) & $604 \pm 180$ & $460 \pm 194$ & 8.235 & $>0.001$ \\
Vegetables $(\mathrm{g})$ & $160 \pm 36.5$ & $100 \pm 41.5$ & 16.359 & $>0.001$ \\
Bread $(\mathrm{g})$ & $370.8 \pm 185.4$ & $282.6 \pm 138.6$ & 5.961 & $>0.001$ \\
Fast food $(\mathrm{g})$ & & & \\
\hline
\end{tabular}

PGD (proinflammatory diet group), NPDG (non-proinflammatory diet group), mL (milliliters), g (grams).

According to the psychological profile, significant differences were found, the PDG presented higher values in openness to experience than the NPDG. The NPDG showed higher values in loneliness; however, the PDG presented lower values in depression. Yet, no group differences were found for extraversion, agreeableness, conscientiousness, neuroticism, and anxiety (Table 4).

Table 4. Differences in psychological and physical activity variables between groups.

\begin{tabular}{|c|c|c|c|c|c|c|}
\hline \multirow[b]{2}{*}{ Variable } & \multirow[b]{2}{*}{ PDG } & \multirow[b]{2}{*}{ NPDG } & \multirow[b]{2}{*}{$\mathbf{t}$} & \multirow[b]{2}{*}{$p$} & \multicolumn{2}{|c|}{$\begin{array}{l}\text { 95\% Confidence } \\
\text { Interval of the } \\
\text { Difference }\end{array}$} \\
\hline & & & & & Lower & Upper \\
\hline Extraversion & $4.57 \pm 1.68$ & $4.82 \pm 1.53$ & -1.715 & 0.087 & -0.529 & 0.036 \\
\hline Agreeableness & $6.37 \pm 1.60$ & $6.13 \pm 1.46$ & 1.774 & 0.077 & -0.026 & 0.512 \\
\hline Conscientiousness & $6.75 \pm 1.73$ & $6.77 \pm 1.59$ & -0.106 & 0.916 & -0.308 & 0.277 \\
\hline Neuroticism & $6.62 \pm 1.85$ & $6.55 \pm 1.86$ & 0.440 & 0.660 & -0.255 & 0.403 \\
\hline Openness to experience & $7.5 \pm 1.53$ & $7.20 \pm 1.54$ & 2.774 & 0.006 & 0.112 & 0.655 \\
\hline AAQII & $23.26 \pm 10.57$ & $25.10 \pm 10.19$ & -1.396 & 0.163 & -1.151 & 0.195 \\
\hline UCLA & $4.91 \pm 1.67$ & $5.14 \pm 1.68$ & -1.976 & 0.049 & -3.666 & -0.011 \\
\hline STAI & $13.16 \pm 3.99$ & $13.64 \pm 3.67$ & -1.518 & 0.130 & -0.526 & 0.068 \\
\hline ZUNG & $48.32 \pm 5.33$ & $49.83 \pm 5.23$ & -3.178 & 0.002 & -2.438 & -0.575 \\
\hline $\begin{array}{l}\text { Average steps per day in the } \\
\text { last week? }\end{array}$ & $2187.14 \pm 3719.03$ & $2455.73 \pm 6160.36$ & -0.565 & 0.572 & -1201.844 & 664.657 \\
\hline $\begin{array}{l}\text { Did you do any physical } \\
\text { activity in the last } 7 \text { days? }\end{array}$ & $1.54 \pm 0.49$ & $1.59 \pm 0.49$ & -1.080 & 0.281 & -0.135 & 0.039 \\
\hline $\begin{array}{l}\text { Minutes of cyclic and/or } \\
\text { aerobic activity }\end{array}$ & $183.22 \pm 205.19$ & $171.61 \pm 198.87$ & 0.405 & 0.686 & -44.943 & 68.168 \\
\hline $\begin{array}{l}\text { Minutes of activity with } \\
\text { self-loading or weights }\end{array}$ & $125.92 \pm 159.81$ & $164.87 \pm 238.77$ & -1.363 & 0.174 & -95.274 & 17.368 \\
\hline
\end{tabular}

AAQII (Acceptance and Action Questionnaire II); UCLA (UCLA Loneliness Scale); STAI (Spielberger StateTrait Anxiety Inventory); ZUNG (Zung Depression Scale); PGD (proinflammatory diet group), NPDG (nonproinflammatory diet group). 
No differences were found in the physical activity habits, when analyzed (Table 4).

\section{Discussion}

The aim of the present research was to study the differences in COVID-19 risk perception of university students, depending on their food consumption (proinflammatory diet and non-proinflammatory diet). We hypothesized that a proinflammatory diet would produce a higher COVID-19 risk perception. The results obtained indicate that participants with a proinflammatory diet had a greater perception of risk towards COVID-19, greater compliance with confinement measures, and a greater sense that their work was more affected by the crisis due to COVID-19.

University students have busy lifestyles as they must adapt to new changes, which are associated with greater independence, class schedules and the demands of their academic responsibilities. For this reason, they often have different dietary behaviors, for example, due to their class schedules, they may skip meals or eat meals quickly [29]. Therefore, several authors have emphasized that the university population is a particularly vulnerable group from a nutritional point of view, since during this period, young people become more aware of their diet [30-33]. In recent years, changes in focus have been observed in studies on diet and health, previously focused on a single nutrient, and now focusing on the quality of the total diet and dietary pattern [34-36]. Some research points out that the dietary pattern of young people is marked by an excessive consumption of meat fats and refined sugars, with a low intake of fruits and vegetables, cereals, legumes, fish, and olive oil $[37,38]$. Other research shows that today's young university students consume sugary, processed and snack foods, and less milk, fish, fruit and vegetables, compared to university students from two decades ago [39]. In this line, some research indicates that university students do not consume enough vegetables, cereals, legumes, and fruits [40]. However, other authors have evaluated the change in eating habits, pointing out that there is a lower consumption of salty snacks, cookies, bakery products, chocolate, and sugary drinks. In contrast, the consumption of fish, fruits, and vegetables has increased [41,42].

Some research has reported changes in food intake over the past year and observed unhealthy dietary patterns [43,44], such as increased consumption of snacks [17], consumption of high glycemic index foods [45], and increased intake of ultra-processed foods [46]. The results of our research found that there is a higher consumption of juices, sugary drinks, fruit, bakery/sweets, meat, fish, legume, pasta or rice, vegetables, bread, and fast food in those students who belonged to the PDG, and higher consumptions of sugary drinks, meat, pasta or rice and fast food; therefore, the high rate of consumption of these foods may be related to inflammation. A healthy and balanced diet is essential, even more so to cope with diseases present today, such as COVID 19, due to the immunomodulatory effects of some nutrients. It has been shown that nutritional deficiencies are associated with increased susceptibility of the person to viral infection and a worse clinical course of the disease $[15,16]$.

Likewise, previous literature reports that unhealthy eating patterns are related to the presence of anxiety and stress [47]. Similarly, consumption of legumes, vegetables, fruits, potatoes, fish, and unrefined olive oil has been shown to be inversely related to depression or anxiety [48]. Other studies suggest that people who consume a proinflammatory diet to a greater extent are more likely to be diagnosed with depression or to show depressive symptoms, compared to those who follow an anti-inflammatory diet [49]. A growing body of research points to the influence of dietary factors on markers of neuronal function and synaptic plasticity, all implicated in the etiology of depression [49,50]. Therefore, a poor diet could produce hyperactivation of the sympathetic autonomic nervous system, producing greater reactivity and therefore greater anxiogenic and depressive symptomatology [20]. In the present investigation, a significant difference in depression values was obtained, being higher in the NPDG, but these were found to be relatively similar in both groups. In relation to loneliness, lower values were obtained in the group consuming a proinflammatory diet, which may be due to this group being confined to living with more people. Other research indicates that higher values of diet quality are associated with a lower perception of 
loneliness and a higher perception of happiness [51]. All this may be related to the results obtained in this study, considering that students who consume a proinflammatory diet have greater uncontrollability and present a greater perception of risk towards COVID-19.

Similarly, the results indicate that this same group had greater compliance with confinement measures and a greater sense that their work has been more affected by the crisis due to COVID-19. Some research indicates that greater compliance with confinement measures may lead people to consume more snacks or an unhealthy meal [9]. Previous literature points out that staying at home due to confinement to reduce the spread of the virus may negatively influence people's diet, as they have greater availability to a wide variety of foods during the day, which may lead to increased caloric intake. Therefore, this confinement situation can generate emotions related to anxiety and frustration, which can lead to an increased need to eat [52]. In this way, other studies point to results similar to those of this research, where greater compliance with confinement may increase the consumption of proinflammatory foods, due to the long periods of time that people spend in their homes [53].

Regarding the physical activity profile, no differences were found; however, physical exercise values are still low considering the minimum daily/weekly physical exercise requirements, which coincides with data found in university students in previous research [54]. Moreover, some authors have suggested that students who do not engage in physical exercise or sport tend to have greater stress reactions, which could lead to a higher intake of a proinflammatory diet [55].

The present research has certain limitations. A causal relationship needs to be tested in future studies. Measurements were obtained through online questionnaires rather than in person. On the other hand, the level of stress was not measured with objective markers, such as alpha amylase, cortisol concentrations, or heart rate variability. For future research, results with objective markers should also be obtained by extending the number of measurements obtained as well as a larger number of participants. In this line, the role of nutrition in mental health during the COVID-19 pandemic is another important fact to consider for continuous research, especially due to the large mental impact of the pandemic in the general population $[56,57]$ as well as in specific populations, such as students [58]. It would be interesting to analyze the role of other factors as physical activity [59], dental health [59,60], psychological profile, especially loneliness [23], and social relationships [61] in the risk perception of COVID-19.

Previous research has already studied the hazard perception of COVID-19 [59]. However, the study of how a proinflammatory diet can modify the perception of COVID-19 risk may be a useful tool to explain and prevent both the psychological and general health consequences of the COVID-19 pandemic in college students. In addition, the use of questionnaires, such as those used in this research, allows for meaningful information to be collected in a short period of time. Knowledge of these related factors could be used by various educational institutions to implement multidisciplinary interventions to reduce this perception of risk to the virus. A future line of research could review whether the results obtained in the present study could be comparable with those of other countries. As a practical application, we recommend reducing the consumption of proinflammatory foods and to follow a balanced diet.

\section{Conclusions}

As discussed, COVID-19 has changed the lifestyles of many people, and also has altered the patterns of work $[2,6]$. In our research, those students consuming a proinflammatory diet had their work more affected by the COVID-19 crisis than those on a non-proinflammatory diet. Likewise, it has been shown that the food consumption patterns of young people throughout the COVID-19 pandemic have undergone changes [9,12]. Several studies have obtained a relationship between diet and people's mood, which may influence the way they perceive and deal with the virus [18]. In this way, the results of our study indicate that students with a proinflammatory diet have a higher level of risk percep- 
tion towards the COVID-19 virus, which is reflected in higher compliance with confinement due to the COVID-19 crisis. These students also presented higher values in openness to experience and lower values in depression and loneliness. Since no significant results were obtained in the physical activity variable, it is not possible to establish a relationship on how proinflammatory diets can affect performance during exercise and whether this exercise can influence psychological variables as well as the perception of risk towards COVID-19. Therefore, studies on how proinflammatory diets may modify the perception of COVID-19 risk may be useful in explaining and preventing the psychological and general health consequences of the COVID-19 pandemic in college students. Furthermore, this type of study could be used to implement multidisciplinary interventions to reduce this perception of risk towards COVID-19. Following the results obtained, a reduction in the consumption of proinflammatory foods and following a balanced diet could be recommended.

Author Contributions: Conceptualization, V.J.C.-S.; methodology, S.R.-B. and V.J.C.-S.; software, S.R.-B.; validation, V.J.C.-S., G.V.-Z., E.B.d.1.R. and S.R.-B.; formal analysis, V.J.C.-S. and S.R.-B.; investigation, V.J.C.-S., G.V.-Z., E.B.d.1.R. and S.R.-B.; writing-S.R.-B., V.J.C.-S., G.V.-Z. and E.B.d.1.R. All authors have read and agreed to the published version of the manuscript.

Funding: This research received no external funding.

Institutional Review Board Statement: The study was conducted according to the guidelines of the Declaration of Helsinki and approved by the European University Ethics Committee (CIPI/18/074).

Informed Consent Statement: Informed consent was obtained from all subjects involved in the study.

Data Availability Statement: All data are presented in the manuscript.

Conflicts of Interest: The authors declare no conflict of interest.

\section{References}

1. World Health Organization (WHO). Coronavirus Disease (COVID-19) Dashboard; WHO: Cham, Switzerland, 2020.

2. Ferry, F.; Bunting, B.; Rosato, M.; Curran, E.; Leavey, G. The impact of reduced working on mental health in the early months of the COVID-19 pandemic: Results from the Understanding Society COVID-19 study. J. Affect. Disord. 2021, 287, 308-315. [CrossRef] [PubMed]

3. Touyz, S.; Lacey, H.; Hay, P. Eating disorders in the time of COVID-19. J. Eat. Disord. 2020, 8, 1-3. [CrossRef] [PubMed]

4. World Health Organization (WHO). COVID-19 Disrupting Mental Health Services in Most Countries, WHO Survey; WHO: Cham, Switzerland, 2020.

5. Cedeño, N.J.V.; Cuenca MF, V.; Mojica Á, A.D.; Portillo, M. Afrontamiento del COVID-19: Estrés, miedo, ansiedad y depresión. Enfermería Investig. 2020, 5, 63-70. [CrossRef]

6. Vergara Castañeda, A.; Lobato Lastiri, M.F.; Díaz Gay, M.; Ayala Moreno, M.D.R. Cambios en el comportamiento alimentario en la era del COVID-19. RELAIS 2020, 3, 27-30.

7. Rishi, P.; Thakur, K.; Vij, S.; Rishi, L.; Singh, A.; Kaur, I.P.; Sanjay, K.S.; Patel, J.-K.L.; Kalia, V.C. Diet, gut microbiota and COVID-19. Indian J. Microbiol. 2020, 60, 420-429. [CrossRef]

8. Dudek, M.; Śpiewak, R. Effects of the COVID-19 Pandemic on Sustainable Food Systems: Lessons Learned for Public Policies? The Case of Poland. Agriculture 2022, 12, 61. [CrossRef]

9. Clemente-Suárez, V.J.; Ramos-Campo, D.J.; Mielgo-Ayuso, J.; Dalamitros, A.A.; Nikolaidis, P.A.; Hormeño-Holgado, A.; TorneroAguilera, J.F. Nutrition in the Actual COVID-19 Pandemic. A Narrative Review. Nutrients 2021, 13, 1924. [CrossRef]

10. Batlle-Bayer, L.; Aldaco, R.; Bala, A.; Puig, R.; Laso, J.; Margallo, M.; Vázquez-Rowe, I.; Antó, J.M.; Fullana-i-Palmer, P. Environmental and Nutritional Impacts of Dietary Changes in Spain during the COVID-19 Lockdown. Sci. Total Environ. 2020, 748, 141410. [CrossRef]

11. Muscogiuri, G.; Barrea, L.; Savastano, S.; Colao, A. Nutritional Recommendations for COVID-19 Quarantine. Eur. J. Clin. Nutr. 2020, 74, 850-851. [CrossRef]

12. Rundle, A.G.; Park, Y.; Herbstman, J.B.; Kinsey, E.W.; Wang, Y.C. COVID-19-Related School Closings and Risk of Weight Gain among Children. Obesity 2020, 28, 1008-1009. [CrossRef]

13. Ruiz-Roso, M.B.; de Carvalho Padilha, P.; Mantilla-Escalante, D.C.; Ulloa, N.; Brun, P.; Acevedo-Correa, D.; Arantes Ferreira Peres, W.; Martorell, M.; Aires, M.T.; de Oliveira Cardoso, L. COVID-19 Confinement and Changes of adolescent's Dietary Trends in Italy, Spain, Chile, Colombia and Brazil. Nutrients 2020, 12, 1807. [CrossRef] [PubMed]

14. Gasmi, A.; Noor, S.; Tippairote, T.; Dadar, M.; Menzel, A.; Bjørklund, G. Individual Risk Management Strategy and Potential Therapeutic Options for the COVID-19 Pandemic. Clin. Immunol. 2020, 215, 108409. [CrossRef] [PubMed] 
15. Bhaskaram, P. Micronutrient Malnutrition, Infection, and Immunity: An Overview. Nutr. Rev. 2002, 60, S40-S45. [CrossRef] [PubMed]

16. Fernandez, M.L.; Raheem, D.; Ramos, F.; Carrascosa, C.; Saraiva, A.; Raposo, A. Highlights of Current Dietary Guidelines in Five Continents. Int. J. Environ. Res. Public Health 2021, 18, 2814. [CrossRef] [PubMed]

17. Mendoza-Castejón, D.; Clemente-Suárez, V.J. Autonomic Profile, Physical Activity, Body Mass Index and Academic Performance of School Students. Sustainability 2020, 12, 6718. [CrossRef]

18. Błaszczyk-Bębenek, E.; Jagielski, P.; Bolesławska, I.; Jagielska, A.; Nitsch-Osuch, A.; Kawalec, P. Nutrition Behaviors in Polish Adults before and during COVID-19 Lockdown. Nutrients 2020, 12, 3084. [CrossRef] [PubMed]

19. Mikolajczyk, R.T.; El Ansari, W.; Maxwell, A.E. Food consumption frequency and perceived stress and depressive symptoms among students in three European countries. Nutr. J. 2009, 8, 1-8. [CrossRef]

20. Shivappa, N.; Schoenaker, D.A.; Hebert, J.R.; Mishra, G.D. Association between inflammatory potential of diet and risk of depression in middle-aged women: The Australian Longitudinal Study on Women's Health. Br. J. Nutr. 2016, 116, 1077-1086. [CrossRef]

21. Clemente-Suárez, V.J. Multidisciplinary intervention in the treatment of mixed anxiety and depression disorder. Physiol. Behav. 2020, 219, 112858. [CrossRef]

22. Lane, M.M.; Davis, J.A.; Beattie, S.; Gómez-Donoso, C.; Loughman, A.; O’Neil, A.; Jacka, F.; Berk, M.; Page, R.; Marx, W.; et al. Ultraprocessed food and chronic noncommunicable diseases: A systematic review and meta-analysis of 43 observational studies. Obes. Rev. 2021, 22, e13146. [CrossRef]

23. Martín-Rodríguez, A.; Tornero-Aguilera, J.F.; López-Pérez, P.J.; Clemente-Suárez, V.J. The Effect of Loneliness in Psychological and Behavioral Profile among High School Students in Spain. Sustainability 2022, 14, 168. [CrossRef]

24. Rammstedt, B.; John, O.P. Measuring personality in one minute or less: A 10-item short version of the Big Five Inventory in English and German. J. Res. Personal. 2007, 41, 203-212. [CrossRef]

25. Van Knippenberg, F.C.E.; Duivenvoorden, H.J.; Bonke, B.; Passchier, J. Shortening the state-trait anxiety inventory. J. Clin. Epidemiol. 1990, 43, 995-1000. [CrossRef]

26. Bond, F.W.; Hayes, S.C.; Baer, R.A.; Carpenter, K.M.; Guenole, N.; Orcutt, H.K.; Waltz, T.; Zettle, R.D. Preliminary psychometric properties of the Acceptance and Action Questionnaire-II: A revised measure of psychological inflexibility and experiential avoidance. Behav. Ther. 2011, 42, 676-688. [CrossRef]

27. Russell, D.W. UCLA Loneliness Scale (Version 3): Reliability, validity, and factor structure. J. Personal. Assess. 1996, 66, 20-40. [CrossRef]

28. Zung, W.W. A self-rating depression scale. Arch. Gen. Psychiatry 1965, 12, 63-70. [CrossRef]

29. Fountoulakis, K.N.; Iacovides, A.; Samolis, S.; Kleanthous, S.; Kaprinis, S.G.; Kaprinis, G.S.; Bech, P. Reliability, validity and psychometric properties of the Greek translation of the zung depression rating scale. BMC Psychiatry 2001, 1, 6. [CrossRef]

30. Welle, P.D.; Graf, H.M. Effective lifestyle habits and coping strategies for stress tolerance among college students. Am. J. Health Educ. 2011, 42, 96-105. [CrossRef]

31. López-Azpiazu, I.; Sánchez-Villegas, A.; Johansson, L.; Petkeviciene, J.; Prattala, R.; Martínez-González, M.A. Disparities in food habits in Europe: Systematic review of educational and occupational differences in the intake of fat. J. Hum. Nutr. Diet. 2003, 16, 349-364. [CrossRef]

32. López Nomdedeu, C. Los Hábitos Alimentarios: Educación y Desarrollo. In Alimentación y Nutrición; Manual Teórico-Práctico; Díaz de Santos: Madrid, Spain, 1998; pp. 267-272.

33. Colić Barić, I.; Šatalić, Z.; Lukešić, Ž. Nutritive value of meals, dietary habits and nutritive status in Croatian university students according to gender. Int. J. Food Sci. Nutr. 2003, 54, 473-484. [CrossRef]

34. Steptoe, A.; Wardle, J.; Cui, W.; Bellisle, F.; Zotti, A.M.; Baranyai, R.; Sanderman, R. Trend in smoking, diet, physical exercise and attitudes toward Health in European University students from 13 countries, 1990-2000. Prev. Med. 2002, 35, 97-104. [CrossRef] [PubMed]

35. Hu, F.B.; Rimm, E.B.; Stampfer, M.J.; Ascherio, A.; Spiegelman, D.; Willett, W.C. Prospective study of major dietary patterns and risk of coronary heart disease in men. Am. J. Clin. Nutr. 2000, 72, 912-921. [CrossRef] [PubMed]

36. Tarasuk, V. Present Knowledge in Nutrition, 7th ed.; International Life Sciences Institute Press: Washington, DC, USA, 1996; pp 508-516.

37. Arroyo Izaga, M.; Rocandio Pablo, A.M.; Ansotegui Alday, L.; Pascual Apalauza, E.; Salces Beti, I.; Rebato Ochoa, E. Calidad de la dieta, sobrepeso y obesidad en estudiantes universitarios. Nutr. Hosp. 2006, 21, 673-679. [PubMed]

38. Ruiz Moreno, E.; Del Pozo de la Calle, S.; Valero Gaspar, T.; Ávila Torres, J.M.; Varela-Moreiras, G. Estudio de Hábitos Alimentarios y Estilos de Vida de Los Universitarios Españoles; Patrón de Consumo de Bebidas Fermentadas; Fundación Española de la Nutrición (FEN): Madrid, Spain, 2012.

39. Cervera Burriel, F.; Serrano Urrea, R.; Vico García, C.; Milla Tobarra, M.; García Meseguer, M.J. Hábitos alimentarios y evaluación nutricional en una población universitaria. Nutr. Hosp. 2013, 28, 438-446. [PubMed]

40. De Piero, A.; Bassett, N.; Rossi, A.; Sammán, N. Tendencia en el consumo de alimentos de estudiantes universitarios. Nutr. Hosp. 2015, 31, 1824-1831. [PubMed]

41. Sánchez Socarrás, V.; Aguilar Martínez, A. Hábitos alimentarios y conductas relacionadas con la salud en una población universitaria. Nutr. Hosp. 2015, 31, 449-457. 
42. Pérez-Rodrigo, C.; Citores, M.G.; Hervás Bárbara, G.; Litago, F.R.; Casis Sáenz, L.; Aranceta-Bartrina, J.; Grupo Colaborativo de la Sociedad Española de Nutrición Comunitaria (SENC). Cambios en los hábitos alimentarios durante el periodo de confinamiento por la pandemia COVID-19 en España. Rev. Esp. Nutr. Comunitaria 2020, 26, 28010.

43. Almendra-Pegueros, R.; Baladia, E.; Contreras, C.R.; Cárdenas, P.R.; Martí, A.V.; Osorio, J.M.; Apolinar Jiménez, E.; Lazzara López, A.; Buhring Bonacich, K.; Nessier, M.; et al. Conducta alimentaria durante el confinamiento por COVID-19 (CoV-Eat Project): Protocolo de un estudio transversal en países de habla hispana. Rev. Nutr. Clín. Metab. 2021, 4, 150-156. [CrossRef]

44. Ammar, A.; Brach, M.; Trabelsi, K.; Chtourou, H.; Boukhris, O.; Masmoudi, L.; Bouaziz, B.; Bentlage, E.; How, D.; Ahmed, M.; et al. Effects of COVID-19 home confinement on eating behaviour and physical activity: Results of the ECLB-COVID19 International online survey. Nutrients 2020, 12, 1583. [CrossRef]

45. Deschasaux-Tanguy, M.; Druesne-Pecollo, N.; Esseddik, Y.; Szabo de Edelenyi, F.; Allès, B.; Andreeva, V.A.; Baudry, J.; Charreire, H.; Deschamps, V.; Egnell, M.; et al. Diet and physical activity during the COVID-19 lockdown period (March-May 2020): Results from the French NutriNet-Sante cohort study. Am. J. Clin. Nutr. 2021, 113, 1-21.

46. Ruíz-Roso, M.B.; de Carvalho Padilha, P.; Matilla-Escalante, D.C.; Brun, P.; Ulloa, N.; Acevedo-Correa, D.; Arantes Ferreira Peres, W.; Martorell, M.; Rangel Bousquet Carrilho, T.; de Oliveira Cardoso, L.; et al. Changes of physical activity and ultra-processed food consumption in adolescents from different countries during COVID-19 pandemic: An observational study. Nutrients 2020, 12, 2289. [CrossRef] [PubMed]

47. Ramón Arbués, E.; Martínez Abadía, B.; Granada López, J.M.; Echániz Serrano, E.; Pellicer García, B.; Juárez Vela, R.; Portillo, S.G.; Sáez Guinoa, M. Conducta alimentaria y su relación con el estrés, la ansiedad, la depresión y el insomnio en estudiantes universitarios. Nutr. Hosp. 2019, 36, 1339-1345. [PubMed]

48. Gibson-Smith, D.; Bot, M.; Brouwer, I.A.; Visser, M.; Giltay, E.J.; Penninx, B.W. Association of food groups with depression and anxiety disorders. Eur. J. Nutr. 2020, 59, 767-778. [CrossRef] [PubMed]

49. Sanchez-Villegas, A.; Galbete, C.; Martinez-Gonzalez, M.A.; Martinez, J.A.; Razquin, C.; Salas-Salvado, J.; Estruch, R.; BuilCosiales, P.; Martí, A. The effect of the Mediterranean diet on plasma brain-derived neurotrophic factor (BDNF) levels: The PREDIMED-NAVARRA randomized trial. Nutr. Neurosci. 2011, 14, 195-201. [CrossRef] [PubMed]

50. Gomez-Pinilla, F. Brain foods: The effects of nutrients on brain function. Nat. Rev. Neurosci. 2008, 9, 568e78. [CrossRef]

51. Mujcic, R.; Oswald, A.J. Evolution of Well-Being and Happiness After Increases in Consumption of Fruit and Vegetables. Am. J. Public Health 2016, 106, 1504-1510. [CrossRef]

52. Romo-Romo, A.; Reyes, C.; Janka-Zires, M.; Almeda-Valdés, P. El rol de la nutrición en la enfermedad por coronavirus 2019 (COVID-19). The role of nutrition in the coronavirus disease 2019 (COVID-19). Rev. Mex. Endocrinol. Metab. Nutr. 2020, 7, 132-143. [CrossRef]

53. Sudriá, M.E.; Andreatta, M.M.; Defagó, M. Los efectos de la cuarentena por coronavirus (COVID-19) en los hábitos alimentarios en Argentina. DIAETA 2020, 38, 10-19.

54. Clemente, F.M.; Nikolaidis, P.T.; Martins, F.M.L.; Mendes, R.S. Physical activity patterns in university students: Do they follow the public health guidelines? PLoS ONE 2016, 11, e0152516. [CrossRef]

55. Valenzuela, M.C.S.; Gallegos, L.I.F.; Baca, L.R.L.; López, H.L.M.; Rico, F.J.F. Estrés académico en universitarios y la práctica de ejercicio físico-deportivo. Rev. Publicando 2021, 8, 1-8. [CrossRef]

56. Clemente-Suárez, V.J.; Navarro-Jiménez, E.; Jimenez, M.; Hormeño-Holgado, A.; Martinez-Gonzalez, M.B.; Benitez-Agudelo, J.C.; Perez-Palencia, N.; Laborde-Cárdenas, C.C.; Tornero-Aguilera, J.F. Impact of COVID-19 pandemic in public mental health: An extensive narrative review. Sustainability 2021, 13, 3221. [CrossRef]

57. Clemente-Suárez, V.J.; Navarro-Jiménez, E.; Ruisoto, P.; Dalamitros, A.A.; Beltran-Velasco, A.I.; Hormeño-Holgado, A.; LabordeCárdenas, C.C.; Tornero-Aguilera, J.F. Performance of Fuzzy Multi-Criteria Decision Analysis of Emergency System in COVID-19 Pandemic. An Extensive Narrative Review. Int. J. Environ. Res. Public Health 2021, 18, 5208. [CrossRef] [PubMed]

58. Clemente-Suárez, V.J.; Martínez-González, M.B.; Benitez-Agudelo, J.C.; Navarro-Jiménez, E.; Beltran-Velasco, A.I.; Ruisoto, P.; Diaz Arroyo, E.; Laborde-Cárdenas, C.C.; Tornero-Aguilera, J.F. The impact of the COVID-19 pandemic on mental disorders. A critical review. Int. J. Environ. Res. Public Health 2021, 18, 10041. [CrossRef] [PubMed]

59. Rodriguez-Besteiro, S.; Tornero-Aguilera, J.F.; Fernández-Lucas, J.; Clemente-Suárez, V.J. Gender differences in the COVID-19 pandemic risk perception, psychology and behaviors of spanish university students. Int. J. Environ. Res. Public Health 2021, 18, 3908. [CrossRef] [PubMed]

60. Martín-Rodríguez, A.; Tornero-Aguilera, J.F.; López-Pérez, P.J.; Clemente-Suárez, V.J. Gender differences in nutritional, odontological and psychological patterns of adolescent students during COVID-19 pandemic. Appl. Sci. 2021, 11, 8499. [CrossRef]

61. Clemente-Suárez, V.J.; Navarro-Jiménez, E.; Moreno-Luna, L.; Saavedra-Serrano, M.C.; Jimenez, M.; Simón, J.A.; Tornero-Aguilera, J.F. The Impact of the COVID-19 Pandemic on Social, Health, and Economy. Sustainability 2021, 13, 6314. [CrossRef] 